\title{
A case study of agroforestry practices and challenges in Mt. Merapi risk and hazard prone area of Indonesia
}

\author{
ZUHUD ROZAKI ${ }^{1, \boldsymbol{\nu}}$, NUR RAHMAWATI ${ }^{1}$, OKI WIJAYA ${ }^{1}$, ATIKAH FAJRIYAH MUBAROK ${ }^{1}$, \\ MASATERU SENGE ${ }^{2}$, MOHD FAUZI KAMARUDIN ${ }^{3}$ \\ ${ }^{1}$ Department of Agribusiness, Faculty of Agriculture, Universitas Muhammadiyah Yogyakarta. Jl. Brawijaya, Kasihan, Bantul 55183, Yogyakarta, \\ Indonesia. Tel./fax.: +62-274-387656, `email: zaki@umy.ac.id \\ ${ }^{2}$ Union Ltd., Gifu, 5010106, Japan \\ ${ }^{3}$ Universiti Teknikal Malaysia Melaka, Jalan Hang Tuah Jaya, 76100 Durian Tunggal, Melaka, Malaysia
}

Manuscript received: 4 May 2021. Revision accepted: 30 May 2021.

\begin{abstract}
Rozaki Z, Rahmawati N, Wijaya O, MubarokAF, Senge M, Kamarudin MF. 2021. A case study of agroforestry practices and challenges in Mt. Merapi risk and hazard prone area of Indonesia. Biodiversitas 22: 2511-2518. This paper presents a case study of agroforestry (AF) practices and challenges in Mt. Merapi risk and hazard prone area of Indonesia. AF has been practiced by farmers in Mt. Merapi risk and hazard prone area from older generation. Each area in Mt. Merapi has different type of AF such as agrisilviculture, silvopasture, and agrosilvopasture. In the village of Glagaharjo, Yogyakarta, this system has been used for land restoration or conservation. $139 \mathrm{AF}$ adopters were chosen from 269 respondents that have been randomly interviewed from four different areas around Mt. Merapi. Statistical descriptive method using values of mean and percentage were used. Additionally, multinomial Logistic regression was utilised to understand the model. The findings of the study shows that the trend of AF is increasing, especially in Glagaharjo, after the 2010 eruption. AF system are also found to be practiced for mitigation strategies in facing Mt. Merapi hazards and risk, especially for crop protection, and land and water conservation. Promoting AF as one of the coping strategies in facing Mt. Merapi hazards and risk is important as indicated by the results of this study.
\end{abstract}

Keywords: Agroforestry, challenges, contribution, Mt. Merapi risk and hazard area

\section{INTRODUCTION}

As an active volcano, Mt. Merapi often erupts. This mountain is located in Central Java and covers three regencies (Boyolali, Klaten and Magelang) and the Special Region of Yogyakarta that covers one District (Sleman). Hardiansyah et al. (2020) explain that historically, many people live in the area of Mt. Merapi because the land is fertile. Beside the perceived danger of being a disaster prone area, people who live in Mt. Merapi, enjoy economic blessings such as fertile land and tourist visits. As stated by Dove (2008), people would not move from Mt. Merapi because of economic motivation and asset preservation (Nofrita and Krol 2014).

At Mt. Merapi, most people are farmers, dairy farmers and sand miners, respectively (Paton et al. 2013) and many felt that it is important for them to keep these livelihoods (Bakkour et al. 2015). Antriyandarti et al. (2013) explain that people in Mt. Merapi risk and hazard-prone areas need to develop their abilities, skills, and knowledge in agriculture because many are practicing agroforestry (AF). This system is a land use management system where trees or shrubs are grown around or among crops or pastureland. This intentional combination of agriculture and forestry has varied benefits, including increased biodiversity and reduced erosion. Jaza Folefack et al. (2019) suggest that using AF or mix cropping could increase yields without over-utilizing the natural forest. This practice is suitable for mountainous areas. Some areas in the world also use this method to cope and conserve the land that is prone to volcanic eruption disasters. In Mt. Merapi, AF is practiced to restore the land that was impacted by previous volcanic eruptions (Fitria and Banowati 2018).

Suryanto et al. (2011) explain that AF has a high level of diversity and can increase land productivity. Lasco et al. (2014) stated that AF systems have emerged as having the potential to enhance the resilience of smallholders to disaster-prone areas. AF consists of several types and each has its own characteristics regarding economic contribution and environmental benefits (Henley 2008).

Despite the hazards and risk of Mt. Merapi, many people are settled there (Surono et al. 2012). People who live in the surrounded areas of Mt. Merapi receive hazards and blessings from Mt. Merapi eruption such as soil that can be used for income generation and/or used to reconstruct the impacted area (Rahman et al. 2016). Other benefits include fertile land from volcanic ash from eruptions (Fiantis et al. 2019).

Mt. Merapi eruptions affect people socio-economically (Maharani et al. 2016). As such, utilizing local potency for economic relief of Mt. Merapi risk and hazard-prone areas is important, such as planting economic crops (Antriyandarti et al. 2013). This is because middle and lowincome people are most severely impacted by Mt. Merapi disasters (Birowo 2011). They need to recover from the economic loss as soon as possible. One agricultural system that is suitable for the Mt. Merapi risk and hazard-prone area with various benefits is AF. 
The practice of AF combines trees with crops or livestock (Russo 1996). Practicing AF is considered as the method to protect the environment whilst increasing prosperity (Suryanto et al. 2021). This system provides many benefits such as providing livelihood, ecosystem services, and others. To promote AF, extension service and education about the benefits of this system need to be provided to the farmers (Amare et al. 2019). Additionally, AF is being practiced in Mt. Merapi, especially the areas close to the top of the volcano, to conserve the land, rehabilitate forest and increase biodiversity. AF also increases community participation in land rehabilitation (de la Cruz and Galang 2006; Suryanto et al. 2011). Without putting additional pressure on crops or forests, AF can increase the yield (Jaza Folefack et al. 2019). In Mt. Merapi, this system has been practiced for a long time and continued to the current generation. This study aims to describe the AF practices and challenges in the Mt. Merapi risk and hazard area.

\section{MATERIALS AND METHODS}

This is a sequential exploratory study that combines both the quantitative and qualitative approaches to extract significant data from the participants. Overall, 269 respondents provide responses to the survey questionnaire adapted from the Rural Household Multi-indicator Survey or RHoMIS (https://www.rhomis.org/). This was followed by semi-structured in-depth interviews with randomly selected participants. The interviews provide deeper and fruitful insights on the survey responses from the respondents based on their knowledge and valuable experiences.

\section{Study area}

Mt. Merapi Volcano is located in two provinces, Central Java and Yogyakarta. This volcano is one of the natural hazards in Indonesia and often erupts (Marfai et al. 2008) One of the biggest eruptions was in 2010, many people died and displaced. The majority of people who live in Mt. Merapi surrounding areas are farmers. The population living in the prone area of Mt. Merapi is about 226,618 people covering 57 villages with a total area of $314.7 \mathrm{~km}^{2}$ (Antriyandarti et al. 2013). People who are living in Mt. Merapi risk and hazard-prone area are facing challenging environments due to hilly and mountainous area (Maharani et al. 2016).

This study was conducted in Mt. Merapi risk and hazard-prone area-Indonesia, covering the East (Jemowo Village, Tamansari Subdistrict, Boyolali District), North (Tlogolele Village, Selo Subdistrict, Boyolali District), West (Krinjing Village, Dukun Subdistrict, Magelang District) and South (Glagaharjo Village, Cangkringan Subdistrict, Sleman District) sections. The National Agency for Disaster Management (BNPB) classified the hazard level of Mt. Merapi based on the radius with the top of Mt. Merapi into ring $1(0-5 \mathrm{~km})$, ring $2(6-10 \mathrm{~km})$, ring 3 $(10-15 \mathrm{~km})$ and ring $4(16-20 \mathrm{~km})$ (BNPB 2010). This study was taken in ring 2 because this area is the closest area to Mt. Merapi that AF can be practiced. Meanwhile, ring 1 is owned by the government and is therefore prohibited for AF practice. Figure 1 below depicts the areas covered in the study.
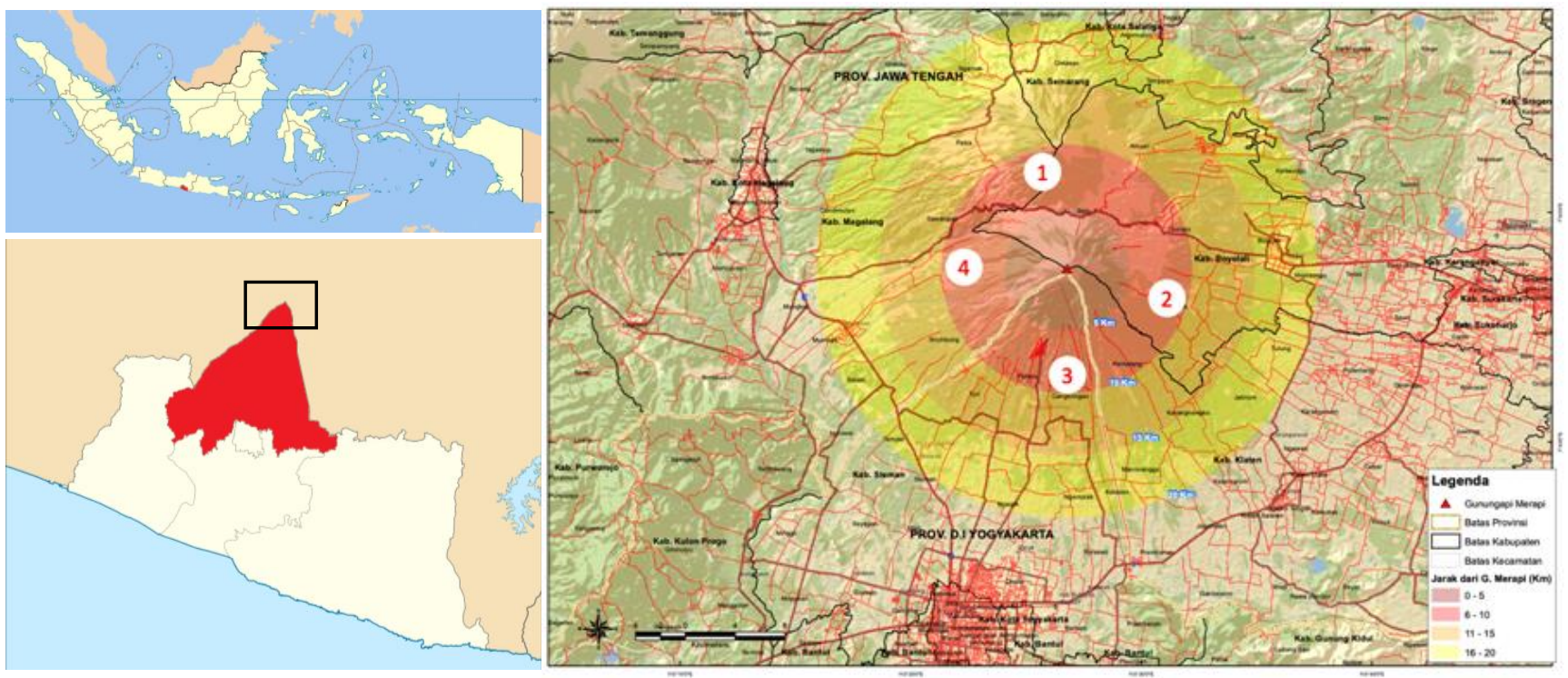

Figure 1. Study area in Mt. Mt. Merapi of Central Java and Yogyakarta provinces, Indonesia: 1. Tlogolele Village, 2. Jemowo Village, 3. Glagaharjo Village, 4. Krinjing Village 


\section{Sampling procedure and data collection}

A total of 139 AF adopters were chosen from 269 respondents that have been randomly interviewed from four different surrounding areas of Mt. Merapi risk and hazard area. The details can be seen in Table 1.

There are three main variables in this study: demographic, AF characteristics, and AF contributions. These variables or indicators were measured with Likert scale and descriptive statistics, as shown in Tables 2, 3, and 4. The questionnaire was constructed from various literature and observation regarding the $\mathrm{AF}$ practices surrounding Mt. Merapi and the people disaster resilience toward volcano activities in many areas in the world (Doberstein 2009; Suryanto et al. 2011; Syaufina 2018). Some questions regarding AF practices were retrieved and modified from Rural Household Multi-indicator Survey or RHoMIS (https://www.rhomis.org/). The research instruments were then analyzed using the validity and reliability tests using Cronbach's alpha test. All questions on the variables are valid and reliable to be used for collecting data. Subsequently, in-depth interviews with key informants and observations were done to complement the findings.

\section{Data analysis}

To present the results, descriptive method is used. Mean, frequency, and percentage were used to describe the variables and know the different characteristics among four different areas. Variables with Likert scale were tested through the validity and reliability tests. Additionally, multinomial logistic regression analysis was used to analyze quantitative data to identify the best set of independent variables (selected demographic and $\mathrm{AF}$ characteristics) predicting the dependent variable (AF contribution). SPSS Version 26 was used to analyze the statistical data.

In order to collect qualitative data, semi-structured indepth interviews and observations were carried out. Interviews with randomly selected respondents were carried out utilizing Charmaz's Constructivist Grounded Theory within the interpretivist paradigm. Interview data was later transcribed verbatim and analyzed through the open, axial, and selective coding for possible emerging themes which subsequently led to plausible theoretical explanations. The transcripts of interviews were provided to the interviewees upon request for validation.

\section{RESULTS AND DISCUSSION}

\section{Demographic characteristics of respondents}

From a total of 139 respondents, male farmers represent $80.58 \%$ (Table 5). Regarding age, $79 \%$ of respondents are in the age range of 28-40 and 41-53 years old.12.95\% of respondents are more than 64 years old, this age is categorized as non-productive age. As with other countries, Indonesia is also faced with the issue of aging farmers since young people are not interested in agriculture (Saiyut et al. 2017).
Table 1. Persons sampled per village

\begin{tabular}{lccc}
\hline Area & $\begin{array}{c}\text { AF } \\
\text { adopters }\end{array}$ & $\begin{array}{c}\text { Non AF } \\
\text { adopters }\end{array}$ & Total \\
\hline Jemowo Village (East) & 35 & 32 & 67 \\
Tlogolele Village (North) & 56 & 65 & 123 \\
Krinjing Village (West) & 12 & 16 & 28 \\
Glagaharjo Village (South) & 36 & 17 & 51 \\
Total & 139 & 130 & 269 \\
\hline
\end{tabular}

Table 2. Demographic variables

\begin{tabular}{|c|c|}
\hline Variable/indicator & Measurement \\
\hline Gender & Male or Female \\
\hline Age & Year, Interval (5 points scale) \\
\hline Education & $\begin{array}{l}\text { None to Diploma or University } \\
\text { ( } 5 \text { points scale) }\end{array}$ \\
\hline Farming experience & Year, Interval (5 points scale) \\
\hline AF experience & Year, Interval (5 points scale) \\
\hline Family number & $\begin{array}{l}\text { None to more than } 5 \text { ( } 5 \text { points } \\
\text { scale) }\end{array}$ \\
\hline $\begin{array}{l}\text { Length of stay (in Mt. Merapi } \\
\text { risk and hazard area) }\end{array}$ & Year, Interval (5 points scale) \\
\hline
\end{tabular}

Table 3. AF characteristic variables

\begin{tabular}{ll}
\hline Variable/indicator & Measurement \\
\hline Type of AF & Descriptive \\
Number of plot & $1-5$ scale \\
Crop or tree type & Descriptive \\
Land size & Interval (5 points scale) \\
AF distance from home & Interval (5 points scale) \\
Land fertility & 1 (very unfertile)-5 (very fertile) \\
AF trend & 1 (decrease)-3 (increase) \\
AF easiness & 1 (very difficult)-5 (very easy) \\
Maintenance & Descriptive \\
\hline
\end{tabular}

Table 4. AF contributions variables

\begin{tabular}{ll}
\hline Variable/indicator & Measurement \\
\hline Food supplier & $\begin{array}{l}1 \text { (strongly disagree)-5 (strongly agree) } \\
\text { Income }\end{array}$ \\
$\begin{array}{l}\text { scales) } \\
\text { Land restoration/ } \\
\text { conservation }\end{array}$ & (strongly disagree)-5 (strongly agree) \\
Water conservation & 1 (strongly disagree)-5 (strongly agree) \\
Crop protection & 1 (strongly disagree)-5 (strongly agree) \\
\hline
\end{tabular}

According to Dinis et al. (2019), education level is important for adoption of agriculture system including adoption of AF. Most respondents had just elementary education, which is $53.96 \%$. The educational level of respondents in the four areas sampled is still mainly elementary. In Jemowo and Tlogolele, only 5.71\% and 7.14 respectively have Diploma or University certificates. In the past, the farmers' education awareness in Indonesia was low. Therefore, many current farmers do not have high education level (Anandita and Patria 2016). 
Table 5. Demographic characteristics of respondents

\begin{tabular}{|c|c|c|}
\hline & Freq. & Percent \\
\hline \multicolumn{3}{|l|}{ Gender } \\
\hline Female & 27 & 19.42 \\
\hline Male & 112 & 80.58 \\
\hline \multicolumn{3}{|l|}{ Age (mean: 46.92) } \\
\hline $15-27$ & 15 & 10.79 \\
\hline $28-40$ & 38 & 27.34 \\
\hline $41-53$ & 41 & 29.5 \\
\hline $54-64$ & 27 & 19.42 \\
\hline More than 64 & 18 & 12.95 \\
\hline \multicolumn{3}{|l|}{ Education } \\
\hline None & 18 & 12.95 \\
\hline Elementary & 75 & 53.96 \\
\hline Junior & 24 & 17.26 \\
\hline High & 16 & 11.51 \\
\hline Diploma/Univ. & 6 & 4.32 \\
\hline \multicolumn{3}{|c|}{ Farming experience (mean: 27.14 ) } \\
\hline $0-10$ & 22 & 15.83 \\
\hline $11-20$ & 30 & 21.58 \\
\hline $21-30$ & 36 & 25.9 \\
\hline $31-40$ & 28 & 20.14 \\
\hline 41 and more & 23 & 16.55 \\
\hline \multicolumn{3}{|c|}{ AF experience (mean: 26.65 ) } \\
\hline $0-10$ & 25 & 17.99 \\
\hline $11-20$ & 28 & 20.14 \\
\hline $21-30$ & 35 & 25.18 \\
\hline $31-40$ & 28 & 20.14 \\
\hline 41 and more & 23 & 16.55 \\
\hline \multicolumn{3}{|c|}{ Household size (mean: 3.29) } \\
\hline 1 or none & 5 & 3.59 \\
\hline 2 & 32 & 23.02 \\
\hline 3 & 42 & 30.22 \\
\hline 4 & 40 & 28.78 \\
\hline 5 or more & 20 & 14.39 \\
\hline \multicolumn{3}{|c|}{ Length of stay (mean: 41.68) } \\
\hline $0-10$ & 8 & 5.75 \\
\hline $11-20$ & 11 & 7.91 \\
\hline $21-30$ & 23 & 16.55 \\
\hline $31-40$ & 24 & 17.27 \\
\hline 41 and more & 73 & 52.52 \\
\hline
\end{tabular}

In terms of farming experience, $25.9 \%$ of the respondents have 21-30 years of experience and $16.55 \%$ of respondents have experienced more than 41 years. For AF experience, the distribution is quite similar with 0-10 years of farming experience representing $17.99 \%$. As for the household size, $81 \%$ of the respondents had a household size of 2-4.

\section{Agroforestry (AF) characteristics \\ Agroforestry type}

There are three types of AF systems practiced by people in Mt. Merapi risk and hazard-prone areas: agrisilviculture, silvopasture, and agrosilvo-pasture (Figure 2). These three types are found to match the people's needs, besides the available natural resource. Agrisilviculture combines food crops and trees (Etshekape et al. 2018), silvopasture combines trees and livestock (Santiago-Freijanes et al. 2018), and agrosilvopasture combining food crops, trees, and livestock (Russo 1996). Each area of Mt. Merapi has its own type of AF. Jemowo (East) is dominated by silvopasture, followed by agrosilvopasture and agrisilviculture respectively. Meanwhile, in Tlogolele (North), it is dominated by agrisilviculture, because this area is higher and the land is suitable for vegetables (Table 6). Hence, applying agrisilviculture benefitted the farmers. Glagaharjo has the same trend as Jemowo, which is dominated by silvopasture. This area is not suitable for vegetables like Tlogolele (Antriyandarti et al. 2013).

\section{Number of plots}

The findings found that people who practice AF have more than one plot. In Jemowo, 26 participants have 2 or 3 plots (Figure 3). In Tlogolele and Krinjing, 4 farmers have 5 plots. In Glagaharjo, no respondents have more than 3 plots. The findings show that not many farmers have more than 3 plots. This reflects the economic background of the farmers in the areas as shown in Figure 3.

\section{Agroforestry trend}

AF has been adopted and practiced by many farmers due to its easiness to be practiced (Utomo et al. 2016), this condition also being proven in this study. Ease of practice of AF based on all areas is quite similar, around 4 in mean (Figure 4). This system has already been practiced from respondents' parents to grandparents. Therefore, they feel that AF is not difficult to practice. The average farm size is less than a half hectare. Jemowo has the lowest average farm size while Tlogolele has the highest average farm size.

The mountainous area makes the distance between home and farmland, including AF land, are challenging and not so close. The distance of land farms to the main road or to the home has an effect on the perceived benefits such as cost and labor movement (Maryati et al. 2020). The distance of AF plot to home varies and the average distance is less than $1 \mathrm{~km}$, this distance is categorized as close distance in rural areas, but in mountainous areas this still challenging. Having farmland far from home is taking time and more labor from the farmers. AF plots that are less than $1 \mathrm{~km}$ are a good distance. In terms of land fertility, Tlogolele is most fertile as compared to others. This is proven by the vegetables planted there. The lowest land fertility is in Glagaharjo, an area more known as sand producer due to the much deposit of sand from eruption (Ariyanti et al. 2020). Additionally, Glagaharjo has experienced the most severe damage from Mt. Merapi in previous eruptions. Therefore, this area has the highest trend of increasing AF practice. Farmers often plant trees to conserve the land after volcanic eruptions sweep away their land.

\section{Agroforestry contribution}

AF contribution in Mt. Merapi risk and hazard-prone areas varies, including food supply, farming income, land restoration/conservation, water conservation, and crop protection. AF adopters have their own reasons to adopt this system based on the farmer's needs and environmental conditions (Kiptot 2015). AF supplies food for Jemowo with a mean of 3.66. Leakey (2014) stated that AF can be used as food resource both for household and commercial usage and this system can help to generate income like the 
case in Krinjing with a mean of 3.56 (Figure 5). This finding is also similar to Bado et al. (2021). Glagaharjo has highest mean on land restoration/ conservation caused by the severe damage from previous volcanic eruptions. Through AF, they can restore and conserve the Glagaharjo land. AF also leads to conservation of water. Krinjing shows the highest mean in water conservation. Additionally, trees from AF practices can protect the food crops with the highest mean in Glagaharjo. Kiyani et al. (2017) stated that AF adoption can increase income, improves soil fertility, and conserve water and soil.

\section{Maintenance}

AF use for maintenance varies. Some respondents do not use fertilizer or other useful plant boosters for trees. This is because the farmers think that the trees do not give many direct benefits. However, some respondents use fertilizers on the trees, usually, they do it together with the crops, even the volume is lesser than the crops. The common thing in all AF adopters is that they will cut branches in the rainy season, to give more sunlight to the crops. Additionally, for Jackfruit, the leaves can be used as fertilizer. It was also found that the AF adopters who have trees near the main road will cut the tree branches, with the help of other farmers for emergency evacuation purposes. Colfer et. al. (2015) stated that AF maintenance brings gender issues, where women are predominant in $\mathrm{AF}$ product selling, and men are predominant for the works that need more strength.

\section{Family income from agroforestry}

AF can contribute to the household economy through product selling (Catacutan and Naz 2015). In this study, family income from AF consists of farming activities and livestock. Through Figure 6, it can be seen that the average income per year from AF practices is not much and ranges from IDR 10 million to IDR 28 million, or about IDR 0.8 million to 2.5 million per month. However, AF is like agriculture whereby the income is uncertain and will be worse when eruption occurs such as in Glagaharjo. In this area, some land was burnt by the Mt. Merapi eruption. When this event happens, all farmers are at high risk. This study too found that AF practices are the farmers' main livelihood. Additionally, some farmers are practicing AF as a second livelihood. The contribution of AF income varies from around $58 \%$ to $90 \%$. Glagaharjo shows the lowest AF income contribution because the farmers are losing their farmland, and many prefer to work as sand miners (Rahman et al. 2016).

Table 6. Crop, tree and livestock type

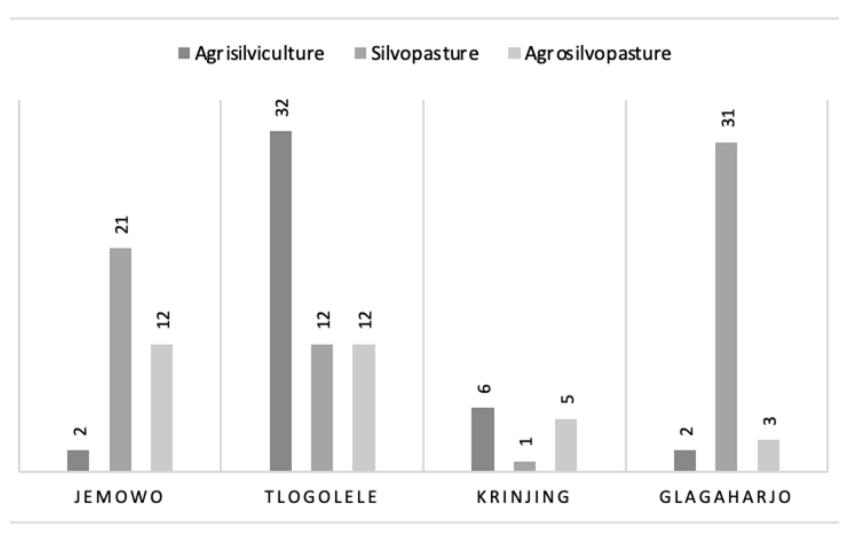

Figure 2. Agroforestry type (Freq.)

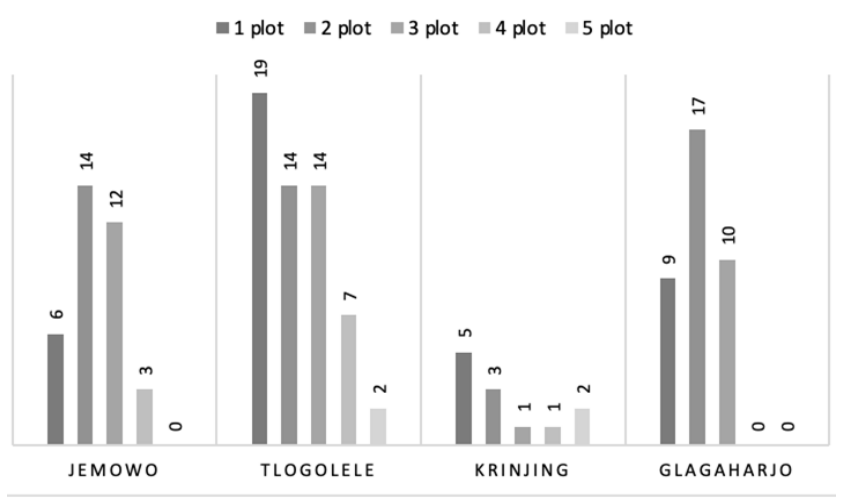

Figure 3. Number of plot (Freq.)

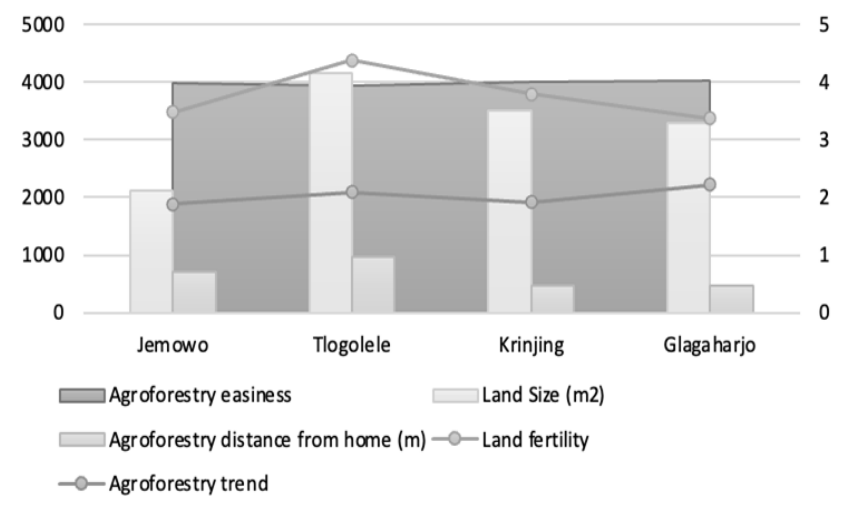

Figure 4. Agroforestry characteristics

\begin{tabular}{|c|c|c|c|}
\hline Area & Crop type & Tree type & Livestock type \\
\hline Jemowo & $\begin{array}{l}\text { Chili, corn, cassava, elephant grass, tobacco, } \\
\text { papaya, banana, ginger, sweet potato, pepper }\end{array}$ & $\begin{array}{l}\text { Clove, avocado, durian, mahogany, } \\
\text { sengon, jengkol, petai }\end{array}$ & $\begin{array}{l}\text { Cow (dairy and meat), } \\
\text { goat, and chicken }\end{array}$ \\
\hline Tlogolele & $\begin{array}{l}\text { Chili, tobacco, cabbage, mustard green, kentucky } \\
\text { wonder, scallion, corn, banana, elephant grass. }\end{array}$ & $\begin{array}{l}\text { Jackfruit, acacia, sengon, avocado, } \\
\text { clove, durian, bamboo, mango, coffee }\end{array}$ & $\begin{array}{l}\text { Cow (dairy and meat), } \\
\text { goat, and chicken }\end{array}$ \\
\hline Krinjing & $\begin{array}{l}\text { Chili, cabbage, kentucky wonder, cassava, } \\
\text { yardlong bean, elephant grass, cucumber, paddy. }\end{array}$ & Coconut, jackfruit, sengon, mahogany & $\begin{array}{l}\text { Cow (dairy and meat) } \\
\text { and chicken }\end{array}$ \\
\hline Glagaharjo & $\begin{array}{l}\text { Chili, strawberry, banana, cassava, scallion, } \\
\text { sweet potato, corn, taro. }\end{array}$ & Acacia, clove, avocado, orange, bamboo & $\begin{array}{l}\text { Cow (dairy and meat) } \\
\text { and chicken }\end{array}$ \\
\hline
\end{tabular}




\begin{tabular}{|c|c|c|c|c|c|}
\hline Glagaharjo & 3.17 & 3.43 & 3.64 & 3.94 & 3.18 \\
\hline Krinjing & 3.25 & 3.56 & 3.31 & 4.08 & 3.08 \\
\hline Telogolele & 3.29 & 3.07 & 3.37 & 3.86 & 3.08 \\
\hline Jemowo & 3.66 & 3.38 & 3.02 & 3.37 & 3.07 \\
\hline \multicolumn{2}{|c|}{0.00} & 5.00 & \multicolumn{2}{|c|}{10.00} & 15.00 \\
\hline \multicolumn{3}{|c|}{ Eood supplier } & \multicolumn{2}{|c|}{ Income } & \\
\hline \multicolumn{6}{|c|}{$=$ Land restoration/ conservation $\varpi$ Water conservation } \\
\hline
\end{tabular}

Figure 5. Agroforestry contribution (mean)

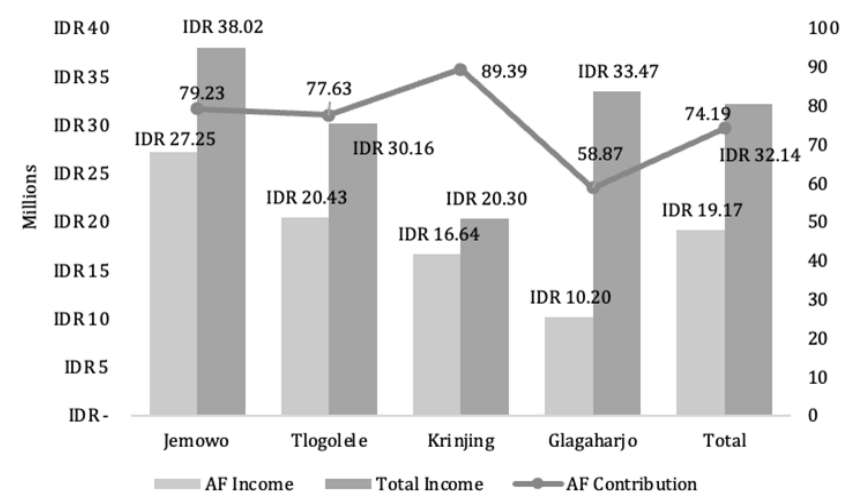

Figure 6. Average agroforestry income per year in millions and contribution to household income in percent

\section{Factors affecting agroforestry contribution to farmers' livelihoods}

The model is fit to be used as indicated by the result of goodness of fit with; 1.000, 0.535, 0.995, 1.000, and 1.000 respectively as seen in Table 7. As indicated by $R^{2}$, the regression models explained between 54\%-97\% of the variance in the data. Every dependent variable has some independent variables that affect the result. Three dependent variables: land conservation, water conservation, and crop protection are parts of mitigation strategies that farmers are using along with AF. This system has been proven to protect the crops from various disasters such as erosion, landslide, and also from eruption materials. This study shows that $\mathrm{AF}$ is believed and has been proven to protect crops. All independent variables have an effect on AF's contribution to crop protection. Land conservation and water conservation have similarities for independent variables that affect age, land size, land fertility, plot number, and length of stay. Meanwhile, education affects land conservation, and household size is affecting water conservation. Kiyani et al. (2017) showed that AF can improve soil fertility, reduce deforestation, and conserve soil and water. Nephawe et al. (2021) stated that water conservation is very important in agriculture. Therefore, $\mathrm{AF}$ contribution to water conservation is many benefiting farmers.

AF also provides income for the adopters. This study shows there is positive significant effect for income from education, family number, farming experience, land size, and length of stay. Education brings farmers to be more likely to listen and adopt new innovation, through this the AF can contribute to more income due to good management and marketing strategy. Family numbers can affect the income because on one side can reduce the labor cost, but on another side can lead the higher AF products to own consumption. Farming experience makes farmers have more abilities and intuition to decide the best method for maintaining their farming, this experience is connected with the length of stay. Land size generally has big effect on the perceived income, bigger the land, farmers can get more production. Bado et al. (2021) showed that AF can optimize land use and increase household income. Meanwhile for food supply variable, only effected by family number and land size. These two variables match with food supply, whereby the more family number a farmer has, the more food from AF is needed. Additionally, the larger the land size, the more food can be produced from $\mathrm{AF}$, farmers also often sell their $\mathrm{AF}$ products to increase their incomes.

Table 7. Factors affecting AF contribution

\begin{tabular}{|c|c|c|c|c|c|c|c|c|c|c|}
\hline & \multicolumn{2}{|c|}{ Income } & \multicolumn{2}{|c|}{ Food supply } & \multicolumn{2}{|c|}{ Land conservation } & \multicolumn{2}{|c|}{ Water conservation } & \multicolumn{2}{|c|}{ Crop protection } \\
\hline & $\begin{array}{c}\text { Chi- } \\
\text { Square }\end{array}$ & Sig. & $\begin{array}{c}\text { Chi- } \\
\text { Square }\end{array}$ & Sig. & $\begin{array}{c}\text { Chi- } \\
\text { Square }\end{array}$ & Sig. & $\begin{array}{c}\text { Chi- } \\
\text { Square }\end{array}$ & Sig. & $\begin{array}{c}\text { Chi- } \\
\text { Square }\end{array}$ & Sig. \\
\hline Age & 8.326 & .759 & 9.703 & .642 & 22.933 & $.028 *$ & 112.189 & $.000 * *$ & 85.373 & $.000 * *$ \\
\hline Education & 25.660 & $.012 *$ & 27.887 & .006 & 140.708 & $.000 * *$ & 10.860 & .541 & 99.855 & $.000 * *$ \\
\hline Family number & 43.238 & $.000 * *$ & 24.370 & $.018 *$ & 18.467 & .102 & 68.917 & $.000 * *$ & 97.124 & $.000 * *$ \\
\hline Farming experience & 27.684 & $.000 * *$ & 3.968 & .681 & - & - & - & - & - & $.000 * *$ \\
\hline AF experience & .846 & .991 & 4.713 & .581 & - & - & - & - & 38.434 & $.000 * *$ \\
\hline AF distance & 8.524 & .743 & 16.695 & .161 & 9.325 & .675 & 10.302 & .589 & 98.157 & $.000 * *$ \\
\hline Land size & 36.639 & $.000 * *$ & 23.192 & $.026 *$ & 231.246 & $.000 * *$ & 47.252 & $.000 * *$ & 81.425 & $.000 * *$ \\
\hline Land fertility & 1.388 & .998 & 4.819 & .850 & 29.542 & $.001 * *$ & 18.308 & $.032 * *$ & 86.130 & $.000^{* *}$ \\
\hline Plot number & 7.869 & .795 & 8.851 & .716 & 241.959 & $.000 *$ & 79.577 & $.000 * *$ & 107.399 & $.000 * *$ \\
\hline Length of stay & 29.686 & $.003 * *$ & 18.538 & .100 & 27.743 & $.006 * *$ & 84.369 & $.000 * *$ & 97.926 & $.000 * *$ \\
\hline Pearson (Goodness of Fit) & \multicolumn{2}{|c|}{1.000} & \multicolumn{2}{|c|}{.535} & \multicolumn{2}{|c|}{.995} & \multicolumn{2}{|c|}{1.000} & \multicolumn{2}{|c|}{1.000} \\
\hline $\mathrm{R}^{2}$ (Nagelkerke) & \multicolumn{2}{|c|}{.912} & \multicolumn{2}{|c|}{.624} & \multicolumn{2}{|c|}{.545} & \multicolumn{2}{|c|}{.937} & \multicolumn{2}{|c|}{.966} \\
\hline
\end{tabular}

Note: *Significant at 0.05 level, $* *$ Significant at 0.01 level 
In conclusion, AF practices in Mt. Merapi risk and hazard-prone areas have started from the older generations. Therefore, the current generation felt that AF practices are not difficult for the system. There are three types of AF that people are practicing: agrisilviculture, silvopasture, and agrosilvopasture. This study shows that AF provides food or income and can become one of the mitigation strategies for Mt. Merapi hazards. The AF system can become the method for land and water conservation, and most importantly as coping strategies for Mt. Merapi hazards and risks. Additionally, crops are used as protection from the Mt. Merapi hazards. Increasing this system practices in Mt. Merapi risk and hazard-prone area will bring good benefits for all parties. The challenge of this system is education of $\mathrm{AF}$ for farmers in the Mt. Merapi risk and hazard area. This is important to increase this system practices and support the prevention actions against Mt. Merapi hazards in the future. Understanding the contribution of AF will lead more farmers to adopt this system. This study shows that AF can contribute to income, food supply, land and water conservation, and crop protection can be used by related stakeholders to promote and educate more farmers so they want to adopt AF.

\section{ACKNOWLEDGEMENTS}

The authors would like to deliver big gratitude to Universitas Muhammadiyah Yogyakarta for funding and supporting this research through an internal research grant. The authors also would like to convey gratitude to Universiti Teknikal Malaysia, Melaka for the collaboration and support.

\section{REFERENCES}

Amare D, Wondie M, Mekuria W, Darr D. 2019. Agroforestry of smallholder farmers in Ethiopia: Practices and benefits. Small-Scale For 18 (1): 39-56. DOI: 10.1007/s11842-018-9405-6.

Anandita DA, Patria KZ. 2016. Agriculture challenges: Decline of farmers and farmland study from Indonesian family life survey. J Ilmu Ekonomi dan Pembangunan 16 (1): 48-53.

Antriyandarti E, Ferichani M, Ani SW. 2013. Sustainability of posteruption socio-economic recovery for the community on Mount Merapi slope through horticulture agribusiness region development (Case study in Boyolali District). Procedia Environ Sci 17, 46-52. DOI: 10.1016/j.proenv.2013.02.010.

Ariyanti V, Gaafar T, De La Sala S, Edelenbos J, Scholten P. 2020 Towards liveable volcanic cities: A look at the governance of lahars in Yogyakarta, Indonesia, and Latacunga, Ecuador. Cities 107 (June 2019): 102893. DOI: 10.1016/j.cities.2020.102893.

Bado BV, Whitbread A, Sanoussi Manzo, ML. 2021. Improving agricultural productivity using agroforestry systems: Performance of millet, cowpea, and Ziziphus-based cropping systems in West Africa Sahel. Agric Ecosyst Environ 305 (September 2019), 107175. DOI: 10.1016/j.agee.2020.107175.

Bakkour D, Enjolras G, Thouret JC, Kast R, Mei ETW, Prihatminingtyas B. 2015. The adaptive governance of natural disaster systems: Insights from the 2010 Mount Merapi eruption in Indonesia. Intl J Disaster Risk Reduction 13: 167-188. DOI: 10.1016/j.ijdrr.2015.05.006.

Birowo MA. 2011. Community media and civic action in response to volcanic hazards. In Crisis Information Management: Communication and Technologies. Woodhead Publishing Limited. DOI: 10.1016/B978-1-84334-647-0.50008-4.

BNPB (Badan Nasional Penaggulangan Bencana). 2010. Peta zonasi bahaya (jarak radius $20 \mathrm{~km}$ ) dari Puncak Gunungapi Mt. Merapi (Hazard Map of Mt. Merapi within $20 \mathrm{~km}$ radius). In: BNPB (Badan Nasional Penaggulangan Bencana) (Issue November). https://bnpb.go.id/ [Indonesian]

Catacutan D, Naz F. 2015. Gender roles, decision-making and challenges to agroforestry adoption in Northwest Vietnam. Int For Rev 17 (4): 22-32. DOI: $10.1505 / 146554815816086381$.

Colfer CJP, Catacutan D, Naz F. 2015. Introduction: contributions and gaps in gender and agroforestry. Int For Rev 17 (4): 1-10. DOI: $10.1505 / 146554815816086471$.

de la Cruz LU, Galang MA. 2006. Initial impacts of forest tree-based agroforestry system on soil properties of a degraded watershed. For Sci Technol 2 (1): 36-41. DOI: 10.1080/21580103.2006.9656297.

Dinis I, Simões O, Cruz C, Teodoro A. 2019. Understanding the impact of intentions in the adoption of local development practices by rural tourism hosts in Portugal. J Rural Stud 72 (November 2018): 92-103. DOI: 10.1016/j.jrurstud.2019.10.002.

Doberstein B. 2009. Post-disaster assessment of hazard mitigation for small and medium-magnitude debris flow disasters in Bali, Indonesia and Jimani, Dominican Republic. Nat Hazards 50 (2): 361-377. DOI: 10.1007/s11069-009-9345-8.

Dove MR. 2008. Perception of volcanic eruption as agent of change on Mt. Merapi volcano, Central Java. J Volcanol Geothermal Res 172 (34): 329-337. DOI: 10.1016/j.jvolgeores.2007.12.037.

Etshekape PG, Atangana AR, Khasa D. 2018. Tree planting in urban and peri-urban of Kinshasa: Survey of factors facilitating agroforestry adoption. Urban For Urban Greening 30, 12-23. DOI: 10.1016/j.ufug.2017.12.015.

Fiantis D, Ginting FI, Gusnidar, Nelson M, Minasny B. 2019. Volcanic ash, insecurity for the people but securing fertile soil for the future. Sustainability (Switzerland) 11 (11): 3072. DOI: $10.3390 /$ su 11113072 .

Fitria A, Banowati E. 2018. Partisipasi masyarakat terhadap pelestarian hutan lereng Mt. Merapi melalui program agroforestri kopi di Desa Tlogolele Kecamatan Selo. Edu Geography 6 (3): 162-169. [Indonesian]

Hardiansyah, Muthohar I, Balijepalli C, Priyanto S. 2020. Analysing vulnerability of road network and guiding evacuees to sheltered areas: Case study of Mt Mt. Merapi, Central Java, Indonesia. Case Stud Transport Policy 8 (4): 1329-1340. DOI: 10.1016/j.cstp.2020.09.004.

Henley D. 2008. Natural resource management: Historical lessons from Indonesia. Hum Ecol 36 (2): 273-290. DOI: 10.1007/s10745-0079137-2

Jaza FAJ, Ngo NMG, Darr D. 2019. Safeguarding forests from smallholder oil palm expansion by more intensive production? The case of Ngwei forest (Cameroon). For Policy Econ 101 (January), 4561. DOI: 10.1016/j.forpol.2019.01.016.

Kiptot E. 2015. Gender roles, responsibilities, and spaces: implications for agroforestry research and development in Africa. Int For Rev 17 (4): 11-21. DOI: 10.1505/146554815816086426.

Kiyani P, Andoh J, Lee Y, Lee DK. 2017. Benefits and challenges of agroforestry adoption: a case of Musebeya sector, Nyamagabe District in southern province of Rwanda. For Sci Technol 13 (4): 174180. DOI: $10.1080 / 21580103.2017 .1392367$.

Lasco RD, Delfino RJP, Catacutan DC, Simelton ES, Wilson DM. 2014. Climate risk adaptation by smallholder farmers: The roles of trees and agroforestry. Curr Opin Environ Sustain 6 (1): 83-88. DOI: 10.1016/j.cosust.2013.11.013.

Leakey RRB. 2014. Agroforestry: Participatory domestication of trees. Encyclopedia of Agriculture and Food Systems 1, 253-269. DOI: 10.1016/B978-0-444-52512-3.00025-5.

Maharani YN, Lee S, Ki SJ. 2016. Social vulnerability at a local level around the Mt. Merapi volcano. Int J Disaster Risk Reduction 20 (July): 63-77. DOI: 10.1016/j.ijdrr.2016.10.012.

Marfai MA, King L, Singh LP, Mardiatno D, Sartohadi J, Hadmoko DS, Dewi A. 2008. Natural hazards in Central Java Province, Indonesia: An overview. Environ Geolog 56 (2): 335-351. DOI: 10.1007/s00254-007-1169-9.

Maryati S, Firman T, Humaira ANS, Febriani YT. 2020. Benefit distribution of community-based infrastructure: Agricultural roads in 
Indonesia. Sustainability (Switzerland) $12 \quad(5): 2085 . \quad$ DOI: $10.3390 /$ su 12052085

Nephawe N, Mwale M, Zuwarimwe J, Tjale MM. 2021. The impact of water-related challenges on rural communities food security initiatives. AGRARIS: J Agribusiness Rural Dev Res 7 (1): 11-23.

Nofrita S, Krol BGCMB. 2014. The livelihood analysis in Mt. Merapi risk and hazard prone area after 2010 eruption. Indones J Geograph 46 (2): 195. DOI: $10.22146 /$ ijg. 5790 .

Paton D, Okada N, Sagala S. 2013. Understanding preparedness for natural hazards: Cross-cultural comparison. J Integrated Disaster Risk Manag 3 (1): 18-35. DOI: 10.5595/idrim.2013.0051

Rahman MB, Nurhasanah IS, Nugroho SP. 2016. Community resilience: Learning from Mt Mt. Merapi eruption 2010. Procedia-Soc Behav Sci 227 (November 2015): 387-394. DOI: 10.1016/j.sbspro.2016.06.090

Russo RO. 1996. Agrosilvopastoral systems: A practical approach toward sustainable agriculture. J Sustain Agric 7 (4): 5-16. DOI: 10.1300/J064v07n04_03.

Saiyut P, Bunyasiri I, Sirisupluxana P, Mahathanaseth I. 2017. Changing age structure and input substitutability in the Thai agricultural sector. Kasetsart J Soc Sci 38 (3): 259-263. DOI: 10.1016/j.kjss.2016.07.004

Santiago-Freijanes JJ, Pisanelli A, Rois-Díaz M, Aldrey-Vázquez JA Rigueiro-Rodríguez A, Pantera A, Vityi A, Lojka B, FerreiroDomínguez N, Mosquera-Losada MR. 2018. Agroforestry development in Europe: Policy issues. Land Use Policy 76 (March): 144-156. DOI: 10.1016/j.landusepol.2018.03.014.

Surono, Jousset P, Pallister J, Boichu M, Buongiorno MF, Budisantoso A Costa F, Andreastuti S, Prata F, Schneider D, Clarisse L, Humaida H, Sumarti S, Bignami C, Griswold J, Carn S, Oppenheimer C, Lavigne F. 2012. The 2010 explosive eruption of Java's Mt. Merapi volcano-A "100-year" event. J Volcanol Geothermal Res 241-242, 121-135. DOI: 10.1016/j.jvolgeores.2012.06.018.

Suryanto P, Hamzah MZ, Mohamed A, Alias MA. 2011. Silviculture agroforestry regime: Compatible management in Southern Gunung Mt. Merapi National Park, Java, Indonesia. Intl J Biol 3 (2): 115. DOI: $10.5539 / \mathrm{ijb} . \mathrm{v} 3 \mathrm{n} 2 \mathrm{p} 115$.

Suryanto P, Sadono R, Yohanifa A, Widyawan MH, Alam T. 2021. Seminatural regeneration and conservation in agroforestry system models on small-scale farmers. Biodiversitas 22 (2): 858-865. DOI: 10.13057/biodiv/d220240.

Syaufina L. 2018. Forest and land fires in Indonesia: Assessment and mitigation. In Integrating Disaster Science and Management: Global Case Studies in Mitigation and Recovery. Elsevier Inc. DOI: 10.1016/B978-0-12-812056-9.00008-7.

Utomo B, Prawoto AA, Bonnet S, Bangviwat A, Gheewala SH. 2016. Environmental performance of cocoa production from monoculture and agroforestry systems in Indonesia. J Cleaner Prod 134 (Part B): 583-591. DOI: 10.1016/j.jclepro.2015.08.102. 